\title{
Relation between Maternal-Fetal Attachment and Gestational Age and Parental Memories
}

\author{
Relação da Vinculação Materno-Fetal com a Idade Gestacional e as Memórias Parentais \\ Relación de la Vinculación Materno-Fetal con la Edad Gestacional y los Recuerdos \\ Parentales \\ Maria Inês Félix Teixeira*; Filomena Martins Marcos Raimundo**; Maria Cristina Quintas Antunes***
}

\begin{abstract}
Background: Attachment is defined as the emotional bond established between the infant and his/her mother or caregiver. It begins to form during pregnancy and will influence the human being, in the relationship with his/her parents and peers, and in the future role as mother/father.

Objectives: To understand the relation between gestational age and maternal-fetal attachment, as well as to analyze the relation between the memories of parental practices and maternal-fetal attachment.

Methodology: A correlational, cross-sectional descriptive study was conducted between January and May, 2015, in a sample consisting of 179 pregnant women at 20 or more weeks of gestation, who were being followed-up in two Healthcare Clusters in the North of Portugal. The Maternal-Fetal Attachment Scale and the Inventory for Assessing Memories of Parental Rearing Behavior were used.

Results: Maternal-fetal attachment increases with gestational age and is correlated with memories of parental practices. Conclusion: Maternal-fetal attachment can be influenced by different aspects, such as gestational age or the memories of parental practices. Thus, it is essential that midwives prepare the pregnant woman both for birth and her role as a mother.
\end{abstract}

Keywords: maternal-fetal attachment; gestational age; memory

\section{Resumo}

Enquadramento: A vinculação é a ligação afetiva do bebé com a mãe ou pessoa que cuida dele. Inicia-se durante a gravidez e influenciará o ser humano, na relação com progenitores, semelhantes e no futuro papel como mãe/pai.

Objetivos: Conhecer a relação entre idade gestacional e vinculação materno-fetal e verificar a relação entre memórias sobre práticas parentais e vinculação materno-fetal.

Metodologia: Realizou-se um estudo descritivo correlacional e transversal, de janeiro a maio de 2013. Participaram 179 grávidas, com idade gestacional igual ou superior a 20 semanas, acompanhadas em dois Agrupamentos de Centros de Saúde do Norte de Portugal. Foram utilizadas a Maternal Fetal Attachment Scale e a Inventory for Assessing Memories of Parental Rearing Behavior.

Resultados: A vinculação materno-fetal aumenta com a idade gestacional e relaciona-se com memórias das práticas parentais.

Conclusão: A vinculação materno-fetal pode ser influenciada por aspetos como idade gestacional e memórias sobre as práticas parentais. Assim é importante que os enfermeiros de saúde materna preparem a grávida para o parto e para o papel de mãe.

Palavras-chave: relação materno-fetal; idade gestacional; memória

\footnotetext{
* MSc., RN, ACES Tâmega III - Vale do Sousa Norte, USF Felgaria Rubeans,4610-102, Felgueiras, Portugal[mift16@gmail.com]. Address for correspondence: Av. Agostinho Ribeiro, 4610-102 Felgueiras, Portugal. Contribution to the article: bibliographic search, data collection, statistical Felgueiras, Portugal. Contribution to the article: bibliographic search, data collection, statistica treatment and evaluation, analysis and discussion of results, article writing.

* MSc., Adjunct Professor, University of Trás-0s-Montes e Alto Douro, 5000-232 Lordelo, Portugal [filomenar@utad.pt] Contribution to the article: collaboration in article writing and revision. *** Ph.D., Psychology, Adjunct Professor, University of Trás-os-Montes e Alto Douro, 5000-232 Lordelo, Portugal [mantunes@utad.pt]. Contribution to the article: Statistical treatment and discussion of results, overall article revision.
}

\section{Resumen}

Marco contextual: La vinculación es la ligación afectiva del bebé con la madre o la persona que cuida de él. Comienza durante el embarazo e influye en el ser humano, en la relación con los progenitores y en el papel futuro como madre/padre. Objetivos: Analizar la relación entre la edad gestacional y la vinculación materno-fetal y verificar la relación entre los recuerdos sobre prácticas parentales y la vinculación maternofetal.

Metodología: Se realizó un estudio descriptivo correlacional y transversal de enero a mayo de 2015. Participaron 179 embarazadas con edad gestacional igual o superior a 20 semanas a las cuales se les hacía el seguimiento en dos agrupamientos de centros de salud del norte de Portugal. Se utilizó la Maternal Fetal Attachment Scale y el Inventory for Assessing Memories of Parental Rearing Behavior.

Resultados: La vinculación materno-fetal aumenta con la edad gestacional y se relaciona con recuerdos de las prácticas parentales.

Conclusión: La vinculación materno-fetal puede verse influida por aspectos como la edad gestacional y los recuerdos sobre las prácticas parentales. De este modo, es importante que los enfermeros de salud materna preparen a la embarazada para el parto y para el papel de madre.

Palabras clave: relación materno-fetal; edad gestacional; memoria

Received for publication: 01.02.15

Accepted for publication: 11.11.15 


\section{Introduction}

Attachment can be defined as the search for proximity or contact with someone and results from the emotional bonding experiences between the infant and the mother or caregiver. This bond is strengthened after birth, but it starts during pregnancy and will influence the child's entire existence, in his/ her relationship with parents and peers, and even in his/her future role as mother/father. Over the years, the importance of this relationship between pregnant woman and fetus has received increased interest from researchers, who aim at understanding the nature of this bond, and how it can affect each individual's personal attitude throughout life.

We formulated the following research question: Is maternal-fetal attachment associated with the gestational age of the current pregnancy and the memories of parental practices? Consequently, we intend to show that prenatal attachment can be influenced by several factors, namely gestational age, and the childhood memories of parental practices. Following the bibliographic search and literature review, we established the following research objectives: to understand the relation between gestational age and maternal-fetal attachment; to analyze the relation between the pregnant woman's memories of parental practices and maternal-fetal attachment.

The research study was conducted between January and May, 2013, in a sample of 179 pregnant women at 20 or more weeks of gestation age attending nursing consultations in functional units (Unidades Funcionais) of two Healthcare Clusters (Agrupamentos de Centros de Saúde, ACES) in the North of Portugal, one predominantly urban, and another predominantly rural.

\section{Background}

Since 1940, the relationship between the infant and his/her caregiver has been the object of several studies in the area of developmental psychology. The first studies on attachment were the joint works of Ainsworth and Bowlby (1991) who, applying concepts from ethology, cybernetics, information processing, developmental psychology and psychoanalysis, reformulated the basic principles of the attachment theory. Bowlby's attachment theory (1952) states that the emotional bond between the mother and the infant affects future relationships and promotes expectations about his/herself and the others that may influence his/her social and psychological development throughout life. According to this perspective, the need to bond with one's significant persons is innate to human beings. This bonding and emotional relationship, referred to by Bowlby (1973) as attachment, seems to start in the uterus, rather than after birth and in the immediate postnatal period, because, as Schmidt and Argimon (2009) believe, the predisposition to create these emotional bonds is already present in the embryo stage. Besides the previously mentioned studies of Bowlby, three scholars put forward their psychoanalytic analyzes on the pregnancy experience: Deutch (1945), Bibring (1959), and Benedek (1959), cited in Brandon, Pitts, Denton, Stringer, and Evans (2009), who explained maternal-fetal attachment as a process in which the pregnant woman's psychic energy is emotionally invested into the fetus. They claim that, as pregnancy progresses, the fetus become more human to the woman, and more loved, not only as an extension of herself, but also as an independent being. This notion raised the academic interest in maternal-fetal attachment.

These scholars were followed by many others, although their studies have been considered unreliable, since no scale had been validated to successfully measure maternal-fetal attachment. In 1981, the first validated scale to measure maternal-fetal attachment - the Maternal Fetal Attachment Scale (MFAS) - was designed by Cranley (1981), with the purpose of measuring the level of attachment between the pregnant woman and the infant still in the uterus. Cranley (1981) defines the maternal-fetal attachment as the intensity with which the pregnant woman expresses behaviors that represent affiliation and integration with the fetus. This author is considered to be the formal developer of the theoretical construct of maternal-fetal attachment (Schmidt \& Argimon, 2009). The validation of the MFAS, which was the first appropriate and effective tool for data analysis, led to an increase of research on maternal-fetal attachment and the development of cross-sectional studies with larger samples, and it is still one of the most widely used tools by researchers (Brandon et al., 2009). 
Throughout the years, many studies have focused on the relation between maternal-fetal attachment and sociodemographic, economic and emotional aspects. These studies have demonstrated that maternal-fetal attachment increases with the gestational age, which, in turn, is related to the perception of fetal movements. Piccinini, Gomes, Nardi, and Lopes (2004) interviewed pregnant women who showed higher levels of satisfaction and self-fulfillment as the gestational age increased, in association with the growth of the fetus and belly. Authors such as Nishikawa and Sakakibara (2013) concluded that maternal-fetal attachment is directly related to the increase of gestational age and the perception of active fetal movements.

On the other hand, parental practices are reflected in the several dimensions of the individual's life, including how a person develops his/her own parenthood (Kobarg, Vieira, \& Vieira, 2010). Thus, the relationship between the pregnant woman and her significant persons can influence the maternal-fetal attachment, assuming that harmonious relations will allow for a greater bond between the pregnant woman and the fetus. Rodrigues et al. (2004), in a study with a sample of pregnant adolescents, observed a higher maternal-fetal attachment when there is a favorable attachment between the pregnant adolescent and the child's father, and her own mother. They also suggested that the expecting mother's memories about her own education are significantly correlated with the quality of attachment to the fetus, i.e. pleasant memories are associated with higher maternal-fetal attachment.

Additionally, the studies conducted by van Bussel, Spitz, and Demyttenaere (2010) confirm that the quality of the mother-infant relationship is strongly associated with how the pregnant woman remembers her own childhood experiences. In a more recent study, Carvalho (2011) concluded that the relationship with the mother is correlated with maternal-fetal attachment: The better the memory of maternal care during childhood, the higher is the attachment between pregnant woman and fetus.

As can be seen, studies show that the decrease of maternal-fetal attachment can be minimized when considering that bad memories of parental practices or an unstable relationship can negatively influence this bond (Rodrigues et al., 2004; Kobarg et al., 2010; van Bussel et al., 2010; Carvalho, 2011).
We believe that the less positive effects that these situations may have on maternal-fetal attachment can be minimized by providing an opportunity to express feelings and an affectionate, supportive and inspiring environment that encourages the pregnant woman to understand her role as a mother. For this reason, it was important to include the memories of parental practices in this study, so as to assess how they are associated with an increase in the quality of maternal-fetal attachment, and compare our results with those from the study carried out by Carvalho (2011) in the center region of Portugal. In summary, we sought to understand the relation between gestational age and maternal-fetal attachment, and analyze the relation between the pregnant woman's memories of parental practices and maternal-fetal attachment, examining these variables within the Portuguese population, and comparing them with other studies, namely the one by Carvalho (2011) in a sample from the center region of Portugal.

\section{Hypotheses}

We formulated the following hypotheses:

$\mathrm{H}_{1}$ - Maternal-fetal attachment increases with gestational age.

$\mathrm{H}_{2}$ - The memories of parental practices are associated with maternal-fetal attachment.

\section{Methodology}

Taking into account the nature and characteristics of the research question, we conducted a non-experimental, descriptive-correlational, cross-sectional study. We used a quantitative methodology, resulting from the analysis of quantifiable data, obtained through the application of a questionnaire, as well as of a Maternal-Fetal Attachment Scale (the MFAS), and a scale on memories of parental practices (the Inventory for Assessing Memories of Parental Rearing Behavior, EMBU).

The sample consisted of 179 pregnant women attending the maternal health consultations in the FUs of two Healthcare Clusters, one predominantly rural and another predominantly urban. The inclusion criteria were: Pregnant women at 20 or more weeks of gestation, who agreed to participate in the study 
and signed the informed consent, and were being followed-up in the clusters between April and June, 2013. The criterion related to 20 or more weeks of gestation is relevant because we wanted to include pregnant women who could already feel the fetal movements. Considering that multiparae feel the fetal movements between weeks 14 and 16 of gestation and primigravidae around week 18 or later (Lowdermilk, 2008), the pregnant women at week 20 of gestation included in the sample would already feel the fetus in the uterus. Furthermore, the MFAS, when applied to pregnant women at the beginning of pregnancy, shows lower levels of reliability (Schmidt \& Argimon, 2009). At this gestational age, most women already know the fetus gender and health status, because they have at least done the first trimester ultrasound, in accordance with the Portuguese Norm No. 23/2011 (Direção Geral da Saúde, 2013).

The independent variables in this study were the gestational age and the memories of parental practices. The dependent variable was the maternal-fetal attachment.

The data collection instrument was a questionnaire divided into three parts: The first part was designed to collect the participants' sociodemographic data; the second part consisted in the application of the MFAS (Feijó, 1999), a scale used to measure the level of maternal-fetal attachment; and, the third part including the EMBU scale (Canavarro, 1996), that measures the memories of parental practices.

The maternal-fetal attachment scale used was the MFAS, which was designed by Cranley (1981) and translated into Brazilian Portuguese by Feijó (1999), with the purpose of measuring the construct of maternal-fetal attachment during pregnancy.

In order to be applied in this study, and since it was translated only into Brazilian Portuguese, the scale was translated into European Portuguese, and applied to a sample of 10 pregnant women (not included in the final sample) who completed the questionnaire, and had the opportunity to pose questions and give their opinion on the possible reformulation of each item of the scale. Thus, after hearing the pregnant women's comments, and given the lack of observations or doubts regarding the translation, the MFAS was applied.

The MFAS is a 24-item Likert scale, with five response options scored from 1 to 5 , in which the higher the score, the higher the level of maternal-fetal attachment. The scale is divided into five subscales: Role taking (items 4, 8, 18, and 19); Differentiation of self from fetus (items $3,5,10$, and 13); Interaction with fetus (items 1, 7, 17, 20, and 24); Attributing characteristics to fetus (items 6, 9, 12, 14, 16, and 21); and Giving of self (items 2, 11, 15, 22, and 23). According to Feijó (1999), this scale is based on the theoretical background of seven authors (Deutsch, Tanner, Bibring, Clark, Rubin, Arbeit, and Leifer). It was tested in 71 pregnant women at the third trimester of pregnancy. Studies on its internal consistency showed a reliability coefficient of 0.85 for the total scale, whereas the reliability of the subscales ranged from 0.52 to 0.73 . The MFAS scores were positively correlated with the available social support reported by women, as well as with their perception of the newborn three days after birth. The author also observed a negative association between the MFAS score and the level of stress perceived by the women (Cranley, 1981). In the study of Feijó (1999), the Cronbach's alpha for the total scale was 0.63 , whereas the scores for the subscales were inaccurate, ranging from 0.52 to 0.83 , which were similar to the original scale. In the present study, the Cronbach's alpha of the subscales Role taking, Interaction with fetus, and Attributing characteristics to fetus ranged from 0.56 to 0.67 , which were reasonable scores. The subscales Differentiation of self from fetus, and Giving of self showed lower reliability coefficients: $\alpha=0.28$ and $\alpha=0.48$, respectively. The total scale showed an acceptable internal consistency coefficient $(\alpha=$ 0.74 ). Since low levels of reliability were found in some scales, only the total MFAS and the subscales with acceptable levels of reliability were used, namely Role taking, Interaction with fetus, and Attributing characteristics to fetus, as mentioned above.

The questionnaire on the memories of parental practices used was the Portuguese short version of the EMBU, validated into Portuguese by Canavarro (1996). This scale measures the frequency of occurrence of a set of rearing practices during childhood and adolescence, in relation to one's mother and father. The EMBU is a Likert-type scale with 23 items regarding each parent, separately, and with four response options: no, never, yes, and always. This scale is divided into three subscales: Emotional warmth (items 2, 6, 9, 12, 14, 19, and 23); Rejection (items 1, 4, 7, 10, 13, 15, 16, 21, and 22), and Over-protection (items 3, 5, 8, 11, 17,18 , and 20). In the study of Canavarro, Cronbach's 
alpha values were slightly below the recommended, both for the total scale $(0.54$ for the father, and 0.66 for the mother) and the different dimensions (ranging from 0.50 to 0.56 for the father, and from 0.64 to 0.69 for the mother; Canavarro, 1996). In the present study, the Cronbach's alpha value for the subscales ranged from 0.51 to 0.83 for the father, and from 0.41 to 0.81 for the mother. Cronbach's alpha values of 0.76 for the father and 0.75 for the mother were obtained in the total scale, which was considered an acceptable reliability. Since the subscale Over-protection had a low level of reliability, it was not used in the study. Only the maternal and paternal version of the total scale and the subscales Emotional warmth and Rejection were applied.

All ethical procedures were followed, without any prejudice to the participants. The request for authorization to use the instruments was submitted and approved by the Health Ethics Committee (Comissão de Ética para a Saúde, CES) of the North Regional Health Administration of the North (Administração Regional de Saúde do Norte, ARSN) and by the Executive Directors of the selected Healthcare Clusters. In addition, all questionnaires included an informed consent form which explained the study characteristics and conditions and ensured the participants' confidentiality and anonymity, informing them that they could withdraw from the study or refuse to participate without any prejudice to themselves or to the relationship with the health professionals.

The Statistical Package for the Social Sciences ${ }^{\circledR}$ (SPSS), version 19.0, for Microsoft Windows ${ }^{\circledR}$, was used for the statistical analysis of the collected data. First, the Cronbach's alpha was calculated to determine the internal consistency of the MFAS and EMBU scales, and to confirm their psychometric properties. The measures of central tendency and dispersion were also used, including the calculation of the mean, mode, and standard deviation of the interval variables. Subsequently, in order to answer the formulated hypotheses, association tests were used in the study to check the inter-variable correlation: Pearson's correlation coefficient and Spearman's rho coefficient.

\section{Results}

Spearman's rho coefficient was calculated to analyze the relation between the gestational age of the current pregnancy and the maternal-fetal attachment. An association was indeed found between both variables, not only in the total scale but also in the subscales Attributing characteristics to fetus (AC) and Interaction with fetus (IF), as shown in Table 1.

Table 1

Spearman's Rho correlations between gestational age and maternal-fetal attachment

\begin{tabular}{lccc}
\hline & AC & IF & MFAS \\
\hline $\begin{array}{l}\text { Rho } \\
\text { (Gestational age) }\end{array}$ & 0.23 & 0.21 & 0.23 \\
\hline$p \leq 0.01$ & & & \\
\hline
\end{tabular}

$p \leq 0.01$.

With regard to the relation between the memories of parental practices and maternal-fetal attachment, and given that the requirements for using a parametric test were met, Pearson's correlation coefficient was calculated, showing a significant correlation between the memories of parental practices and maternal- -fetal attachment, in particular in the EMBU subscale Rejection, and the MFAS subscale Role taking, which showed an inverse relationship (Table 2): The higher the score for childhood memories of rejection by the father and mother, the lower was the maternal-fetal attachment, and vice versa.

Table 2

Pearson's correlation coefficients between memories of parental practices and maternal-fetal attachment

\begin{tabular}{lcc}
\hline & Re Father & Re Mother \\
\hline Maternal-fetal attachment (role taking) & -0.18 & -0.17 \\
\hline
\end{tabular}

Note: Re Father - Rejection by Father; Re Mother - Rejection by Mother; $p \leq 0.05$ 


\section{Discussion}

This study included pregnant women at all gestational ages, between week 20 and 40 of gestation, with a mean of 29.13 weeks of gestation ( \pm 5.72). As expected, this study revealed a very significant correlation between the gestational age and the maternal-fetal attachment total scale and subscales Interaction with fetus and Attributing characteristics to fetus. In fact, as the gestational age increases, it is natural for pregnant women to interact more with their unborn child, by talking to him/her, calling him/ her by name, caressing him/her, and stimulating him/ her to respond to their actions. These results were also observed in the study of Masera, Martín, and Pavón (2011). Pregnant women also feel encouraged to try and guess the infants' personality according to his/her movements, and wonder if they can hear, think and feel while still in the uterus. All these factors seem to bring pregnant women an increased sense of safety and fulfillment, which contributes to an increased maternal-fetal attachment: "One of the feelings expressed by pregnant women was a satisfaction with the transformations that occurred, which foreground them . . . besides providing them a feeling of safety and certainty about their pregnant condition" (Piccinini et al., 2008, p. 65). Additionally, the study of Nishikawa and Sakakibara (2013) emphasized that as the gestational age increases, the fetus and the belly grow, and the feeling of active fetal movements increases, the maternal-fetal attachment and sense of self-fulfillment of the pregnant woman also increase.

However, no significant correlation was found with the gestational age increase in the subscale Role Taking, probably because, from the mother's perspective, the activities resulting from this subscale are not inherent to the whole pregnancy process, not being related to the gestational age. From this point of view, regardless of the gestational age, or even before becoming pregnant, the woman envisions her future role as a mother. This perception is probably associated with other variables which are not related to pregnancy.

According to the results obtained in this study, the memories of parental practices seem to be related to the maternal-fetal attachment, particularly in what concerns the relation between the EMBU subscale Rejection (father and mother) and the MFAS subscale Role taking. This result could mean that the perception of rejection by her mother and/or father during childhood can jeopardize the development of the pregnant woman's perception of her role as a future mother, to the extent that she may think that she lacks the skills to perform her role, namely provide neonatal care and breastfeed. Previous studies, although not focused on the dimensions studied here, also found a correlation between the memories of parental practices and maternal-fetal attachment. Rodrigues et al. (2004), van Bussel et al. (2010), and Carvalho (2011) showed that the maternal-fetal attachment is positively and significantly correlated with the memory of parental care. It is therefore confirmed that the higher the positive memory of maternal care, the greater is the maternal-fetal attachment. This explanation is, however, a mere speculation, and this study must be replicated, since the correlation was significant but weak.

Regarding the limitations and difficulties in conducting this study, although the sample has a high sociodemographic diversity, a significant number of participants, and a random sampling method (with the concern of including participants from a rural and an urban environment), all the respondents lived in the northern region of Portugal. This factor should be taken into account in a potential generalizability of the results to the general population. The scale used for the assessment of maternal-fetal attachment has been criticized in the literature (Brandon et al., 2009), although it is one of the most viable and widely used instruments to assess maternal-fetal attachment. Despite this, new knowledge emerges from this study, namely an improved understanding about some of the factors that may influence maternal-fetal attachment (gestational age and memories of parental practices) and the extent to which nurses, and in particular midwives, may help the pregnant woman to develop and improve her perception about her future role as a mother, and to effectively prepare for motherhood.

\section{Conclusion}

Regarding the hypothesis of maternal-fetal attachment increasing with gestational age, we concluded that the variables are significantly correlated, especially in the subscales Interaction with fetus and Attributing characteristics to fetus. The reviewed studies 
(Piccinini et al., 2008; Masera et al., 2011; Nishikawa \& Sakakibara, 2013) corroborate this research hypothesis. Therefore, health professionals, in particular midwives, must provide emotional support and help in the adaptation process during pregnancy, especially after the pregnant woman is able to perceive fetal movements, assisting in the development of the mother/infant relationship, even before birth.

In what concerns the hypothesis of the memories of parental practices being related to maternal-fetal attachment, a significant correlation was found between the variables, especially in the dimensions of Rejection by the father and mother (EMBU subscale), and Role taking (MFAS subscale). This may indicate that the higher the positive memory of parental care, the higher is the level of maternal-fetal attachment reported by the pregnant woman, which is in line with similar results obtained in previous studies (Carvalho, 2011; Rodrigues et al., 2004; van Bussel et al., 2010). For these reasons, we conclude once again that nurses, in particular midwives, seem to become highly relevant in monitoring the pregnant woman, among other aspects, by allowing the pregnant woman to tell her memories of parental practices so as to identify any less positive feelings and perceptions about the performance of her future role as a mother.

Therefore, the empirical data obtained in this study call for the need for midwives to monitor the pregnant women's psychological needs. Our study also revealed that, rather than with social-economic factors, maternal-fetal attachment is more associated with pregnancy-related factors, such as the perception of fetal movements, and with memory-related factors, such as the memories of parental practices.

For future research purposes, we consider that it will be important to study the association between maternal-fetal attachment and other factors, namely the pregnant women's ethnicity (culture), as well as other psychosocial variables, such as feelings of anxiety and depression, and analyze how these factors can influence the attachment between the pregnant woman and the fetus.

\section{References}

Ainsworth, M. D., \& Bowlby, J. (1991). An ethological approach to personality development. American Psychologist, 46(4), 333341. Retrieved from http://www.psychology.sunysb.edu/ attachment/online/ainsworth_bowlby_1991.pdf
Bowlby, J. (1952). Maternal care and mental bealth: A report prepared on behalf of the World Health Organization Monograph (2a ed.). Geneva, Switzerland: WHO.

Bowlby J. (1973). Separation: Anxiety \& Anger. London, United Kingdom: Hogarth Press.

Brandon, A. R., Pitts, S., Denton, W. H., Stringer, A., \& Evans, H. M. (2009). A history of the theory of prenatal attachment. Journal of Prenatal and Perinatal Psychology and Health, 23(4), 201-222. Retrieved from http://www.ncbi.nlm.nih.gov/ pmc/articles/PMC3083029/

Canavarro, M. C. (1996). A avaliação das práticas educativas através do EMBU: Estudos psicométricos. Psychologica, 16, 5-18.

Carvalho, M. E. (2011). O bebé imaginário, as memórias dos cuidados parentais e as representações sonoro-musicais na gravidez no estudo da representação da vinculação materna pré-natal e da orientação para a maternidade (Unpublished PhD Thesis). Universidade de Lisboa, Portugal.

Cranley, M. S. (1981). Development of a tool for the measurement of maternal attachment during pregnancy. Nursing Research, 30(5), 281-284.

Direção Geral da Saúde. (2013). Norma 23/2011: Exames ecográficos na gravidez de baixo risco. Lisboa, Portugal: Autor.

Feijó, M. C. (1999). Validação brasileira da maternal fetal attachment scale. Arquivos Brasileiros de Psicologia, 51(4), 52-62.

Kobarg, A. P., Vieira, V., Vieira, M. L. (2010). Validação da Escala de Lembranças sobre Práticas Parentais (EMBU). Avaliação Psicológica, 9(1), 77-85. Retrieved from http://www.redalyc. org/articulo.oa?id=335027281009

Lowdermilk, D. (2008). Anatomia e fisiologia da gravidez. In D. Lowdermilk \& S. Perry, Enfermagem na maternidade ( $7^{\mathrm{a}}$ ed., pp. 222-244). Loures, Portugal: Lusodidacta.

Masera, R. G., Martín, P. A., \& Pavón, I. R. (2011). Relación materno fetal y establecimiento del apego durante la etapa de gestación. International Journal of Developmental and Educational Psychology, 1(1), 425-434. Retrieved from http://infad.eu/RevistaINFAD/2011/n1/volumen1/ INFAD_010123_425-434.pdf

Nishikawa, M., \& Sakakibara, H. (2013). Effect of nursing intervention program using abdominal palpation of Leopold's maneuvers on maternal-fetal attachment. Reproductive Health Journal, 10(12), 1-7. doi:10.1186/1742-4755-10-12

Piccinini, C. A., Gomes, A. G., Nardi, T. D., \& Lopes, R.S. (2004). Gestação e constituição da maternidade. Psicologia em Estudo, 13(1), 63-72. Retrieved from http://www.scielo.br/ pdf/pe/v13n1/v13n1a07.pdf

Schmidt, E.B., \& Argimon, I. I. (2009). Vinculação da gestante e apego materno-fetal. Paidéia, 19(43), 211-220. Retrieved from http://www.scielo.br/scielo.php?pid $=$ S0103863X2009000200009\&script $=$ sci $\_$arttext 
Rodrigues, S., Figueiredo, B., Pacheco, A., Costa, R., Cabeleira, C., \& Magarinho, R. (2004). Memória de cuidados na infância, estilo de vinculação e qualidade da relação com pessoas significativas: Estudo com grávidas adolescentes. Análise Psicológica, 22(4), 643-665. Retrieved from e http:// repositorium.sdum.uminho.pt/bitstream/1822/4226/1/
Mem\%C3\%B3ria\%20de\%2 0cuidados\%2 0na\%20 inf\%C3\%A2ncia\%20\%282004\%29.pdf

van Bussel, J. C., Spitz, B., \& Demyttenaere, K. (2010). Reliability and validity of the Dutch version of the maternal antenatal attachment scale. Archives of Women's Mental Health, 13 (3), 267-277. doi: 10.1007/s00737-009-0127-9 